\title{
Youth Entrepreneurship in Visegrad Countries
}

\author{
Marian Holienka, Anna Pilková, Zuzana Jančovičová
}

\begin{abstract}
A B S T R A C T
Objective: The aim of our paper is to analyse the entrepreneurial activity drivers of youth and young adults in Visegrad countries, considering the opportunity/necessity motivation dichotomy.

Research Design \& Methods: We employ the Global Entrepreneurship Monitor data for young individuals (18 to 34 years) from V4 countries for years 2011 to 2013. We use the binomial logistic regression modelling with logit transformation. Separate models are constructed for youth and young adults, as well as for opportunity- and necessity-driven entrepreneurial activity.

Findings: We found common drivers and distinctive attributes affecting involvement of young people in business start-up according to its motivation. Self-confidence and access to networks are universally important factors. In most examined cases, fear of failure and being a female reduces chance of business start-up. Especially among youth, being a student significantly inhibits involvement in enterprising efforts.

Implications \& Recommendations: In order to support youth entrepreneurship, emphasis should be put on education and training to build skills and knowledge required for business start-ups, together with capacity to spot opportunities, and reduce fear of failure. Formal and informal networking plays an important role in youth entrepreneurship.
\end{abstract}

Contribution \& Value Added: Based on empirical analysis, our findings point out the key drivers of entrepreneurial activity among young people in V4 countries. We show directions for policy makers aiming to foster entrepreneurship within young generation as both way to exploit available business opportunities, as well as reaction to necessity situations.

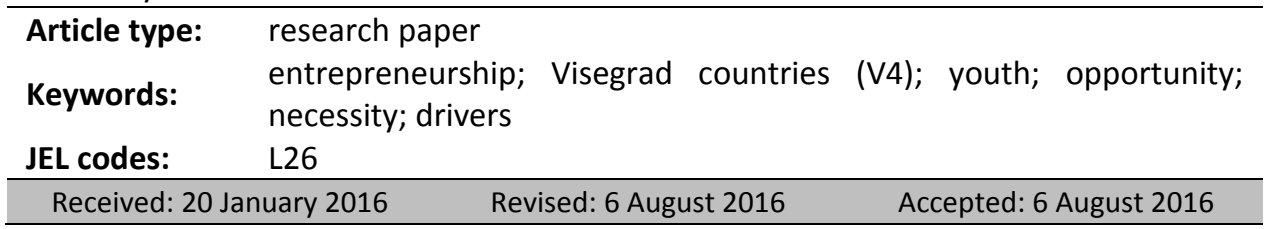

\section{Suggested citation:}

Holienka, M., Pilková, A., \& Jančovičová, Z. (2016). Youth Entrepreneurship in Visegrad Countries. Entrepreneurial Business and Economics Review, 4(4), 105-121, DOI: http://dx.doi.org/10.15678/EBER.2016.040407 


\section{INTRODUCTION}

The issue of youth entrepreneurship is, from the macroeconomic perspective, aimed mainly on economic and societal dimensions of this phenomenon (Holienka, 2014). Entrepreneurship is perceived as one of the potential solutions to youth unemployment, which has become a particularly hot topic throughout entire Europe. Its solution lies not only in self-employment, but also in potential for creation of other jobs. Especially regarding young individuals, the issue has also other important dimension. It is the age group in the beginning or in early stages of economic activity. If they decide for entrepreneurship as their career choice, they will hopefully become economically selfsufficient and will create their own jobs instead of looking for them, and potentially also create jobs for other people. Thus, such decision in early phases of economic activity is a good assumption (however, not a matter of course) that individuals will follow the selfsufficiency during the entire economic active age and contribute to the development of quantity as well as qualitative side of entrepreneurial activity in an economy.

Moreover, youth entrepreneurship is a highly important phenomenon also in the context of current development of economies. The immense growth of innovation brings trends such as constant dynamics and instability, rapid changes or increased cognitive complexity (Integral Assets Consulting, 2006). These lead to changing nature of labour, and to need for application of enterprising attributes not only for profit businesses, but also in the role of employee or in many other different social roles. Formation of such skills is therefore not only the way towards development of independent, profit-oriented entrepreneurship. On contrary, its role is to support creativity, innovativeness and ability to identify opportunities and bring ideas into life, thus equipping young people with "enterprising mindset" that can be utilized in many different activities.

To foster their involvement in entrepreneurship, policy makers need to understand the factors leading young individuals towards enterprising efforts. Former research has shown that, in relation to entrepreneurship, young people and mature people are different in several areas, including accumulation of resources and skills; psychological, cognitive and motivational attributes; and reaction to influences from the environment, culture and norms (Minola, Criaco \& Cassia, 2014). However, generalising the drivers of youth entrepreneurship may be too oversimplifying. With this respect, at macro level, we need to consider at least two other dimensions - age cohorts and motivation. It is clear that the group referred to as young individuals is rather large and heterogeneous. One perspective on this divergence considers whether an individual is already economically active or still in the phase of preparation for future occupation. These two stages are substantially diverse, which implies their difference in relation to entrepreneurship. Regarding motivation, entrepreneurial activities may arise from wide variety of different motives. Generally, these motives can be well classified into two main categories - opportunity and necessity. By definition, these two types refer to different underlying life situations that may reflect potential drivers of business start-up in different way. Without specific preference to any of them, it is important to understand mechanism behind both these types of entrepreneurship.

The aim of our paper is to analyse the entrepreneurial activity drivers of youth and young adults in Visegrad countries, considering the opportunity/necessity motivation 
dichotomy. To do so, we employ the Global Entrepreneurship Monitor 2011 to 2013 individual-level data in a pooled sample from V4 countries and perform a binomial logistic regression analysis in search for drivers significantly affecting individual involvement of youth and young adults in early-stage entrepreneurial activity out of opportunity and necessity.

The structure of our paper is standard. In the following section we provide a review of literature on youth entrepreneurship, its drivers, as well as nature and role of necessity and opportunity motivation to start a business. Section 3 describes the materials and methods employed in our analysis, while Section 4 presents and discusses its results and main findings.

\section{LITERATURE REVIEW}

\section{What Does It Mean "Youth" in Entrepreneurship Context?}

The first question that needs to be clarified when dealing with youth entrepreneurship is the definition of "youth". In fact, there is no universal definition of youth neither generally nor in this specific context. For example, United Nations understands youth as individuals in the age of 15 to 24, but it also accepts the existence of definitions used by other countries of entities (United Nations, 2014). One of such is the definition used in the EU, where Eurostat considers youth as individuals in the age of 15 to 29 years (European Commission, 2009).

Especially in relation to entrepreneurship, Chigunta (2002) introduced definition and classification of youth entrepreneurship from qualitative perspective through "transitional categorization" based on structural differences between entrepreneurial activities of young people in different age. It recognizes three main phases of youth entrepreneurship. It also stresses that the transitional process is not necessarily linear, and the age categorization is not strict either, because the transfer between phases may differ in particular economies or industries. The first "pre-entrepreneurship" phase (15 to 19 years) represents a forming phase or some trial period. Young people usually find themselves in this phase during the transfer from "family nest" or educational process to the position of economically active individuals. The second "budding entrepreneurship" phase (20 to 25 years) reflects a growth phase in which young individuals can already possess certain experience, skills or capital, enabling them to run their own business activities. Finally, the third phase of "emergent entrepreneurship" (26 to 29 years) is the main phase where young entrepreneurs are, thanks to experience acquired (not only) in entrepreneurship, more mature than younger individuals, thus increasing the chance that they can successfully manage a vital business activity.

However, for the purpose of our analysis based on GEM data, we need to follow clearly defined age criteria. Thus, we incline to the GEM perspective, where youth entrepreneurship includes individuals in the age from 18 to 34 years (Kew, Herrington, Litovsky \& Gale, 2013). Due to heterogeneity in such broad category, we further distinguish between the youth (18 to 24 ) and young adults (25 to 34), which also corresponds with the GEM perspective (Pilková, Holienka, Kovačicová \& Rehák, 2014). This distinction reflects the specifics of these two groups and their position in an economy. Youth usually find themselves at the doorstep of economic activity. There, some individuals still remain 
in the process of preparation for their occupation, while the others are fully involved among either workforce or self-employed, or they attempt to include into economically active life. On contrary, among young adults, the preparation to occupation has usually been completed, and an active participation in the economic activity within the society is anticipated.

\section{Drivers of Youth Entrepreneurship}

The research on youth entrepreneurship is mainly focused on factors influencing the entrepreneurial activity, both in its quantity as well as quality (Pilková et al., 2014). The most frequently studied drivers of individual involvement in entrepreneurial activity are the individual entrepreneurship-related attributes, social capital and perception of societal attitudes, and individual demographic characteristics. Since former research indicates rather general validity than age-specific nature of these drivers, we will consider the full scope of these potential factors in our analysis.

Individual demographic characteristics studied for their influence on taking the entrepreneurial path are mainly gender, educational attainment and household income. Gender studies suggest that the entrepreneurial propensity of men and women may be influenced by differences attributed to gender-specific characteristics (Langowitz \& Minniti, 2007). Most empirical studies found that, despite considerable recent growth in their inclusion, women still tend to be underrepresented in entrepreneur population (Davis, 2012; Bjerke, 2013). The assumptions about effect of educational attainment is related to the concept of human capital, representing a knowledge base determining the individual's capacity to recognize and pursue entrepreneurial opportunities (RamosRodríguez, Medina-Garrido, Lorenzo-Gómez \& Ruiz-Navarro, 2010). Previous empirical research proved human capital, partially operationalized through educational attainment, to be positively related to nascent entrepreneurship (Kim, Aldrich \& Keister, 2006). Finally, the role of household income can be viewed through the financial resources perspective, especially with the opportunity costs of reducing this income. According to $\mathrm{Kim}$ et al. (2006), at lower income levels, individuals may consider the opportunity costs of starting business very low, while at higher income levels, individuals may perceive that the loss of their current income outweighs prospective (and still uncertain) gains from a new business (Kim et al., 2006), thus abstaining from business start-up.

The most commonly investigated individual attributes related to the involvement in entrepreneurial activity are alertness to business opportunities, entrepreneurial selfconfidence, and fear of failure. Alertness to business opportunities is related to individual subjective perception of good opportunities for starting up and running an enterprise. According to Kirzner (1979), such alertness is a key perceptual characteristic of entrepreneurial behaviour and a necessary precondition for entrepreneurial action. It has been proven as an important driver of engagement in enterprising efforts (Arenius \& Minniti, 2005; Koellinger, Minnitic \& Schaded, 2007). Entrepreneurial self-confidence relates to the concept of self-efficacy, that represents one's judgement of own ability to execute an action and produce designated levels of performance (Bandura, 1994). Thus, it has been established as a reliable predictor of different goal-directed behaviours, including entrepreneurship. Self-efficacy is strongly related to perceived behavioural control and ability, which together with attitude toward behaviour and subjective norm influence the intention, that in turn affects the actual behaviour of an individual (Ajzen, 1991). In case of 
entrepreneurship, the context-specific self-efficacy represents the self-confidence of an individual in having the required skills, experience and abilities to successfully start-up and run a business. Previous empirical studies have proven the positive relationship between high levels of self-efficacy and individual entrepreneurial activity (Arenius \& Minniti, 2005; Lukeš, Zouhar, Jakl \& Očko, 2013; Wong \& Lee, 2005). Fear of failure represents a subjective perception regarding the risk of entrepreneurial failure and its possible consequences. Since the majority of individuals are supposed to be risk-averse by nature, increased fear of failure is expected to act as an inhibitor of entrepreneurial action (Arenius \& Minniti, 2005). Empirical research has provided certain evidence supporting these assumptions considering entrepreneurial activity (Arenius \& Minniti, 2005; Lukeš et al., 2013; Wagner, 2007).

Social capital generally refers to social networks of an individual that enable to extract benefits from these social structures, networks and memberships through the social exchange (Portes, 1998). It represents an external knowledge provided by other people in the entrepreneur's environment (Ramos-Rodríguez et al., 2010), which foster the discovery of opportunities, their exploitation as well as the identification, collection and allocation of scarce resources (Davidsson \& Honig, 2003). One of the most relevant sources of social capital for early-stage entrepreneurs are other individuals with recent business start-up experience. Empirical research has already identified positive impact of knowing an entrepreneur on involvement in entrepreneurship (Lukeš et al., 2013).

Perception of societal attitudes towards entrepreneurship represents an individual perception of social norms, values, beliefs and assumptions socially carried by individuals within the society and influencing their behaviour. In other words, we speak about institutions (North, 1990). They shape the entrepreneurial activity of individuals who try to adjust their actions to achieve conformity in the environment shaped by these institutions. One of them is the status of successful entrepreneurs in a society. If an individual believes successful entrepreneurs enjoy high levels of social status and respect, he will be generally more likely to find entrepreneurial activity desirable. He would perceive that by joining an entrepreneurial path he would achieve legitimacy by conforming to norms and values within society (Lonsburry \& Glynn, 2001).

\section{Opportunity and Necessity Motives and Entrepreneurship Drivers}

There is a wide range of different motives behind the decision to start a business. Simply, within the GEM perspective, they are divided into the two main categories - opportunity and necessity motives (Reynolds, Camp, Bygrave, Autio \& Hay, 2001). The question is, how these motives moderate the generally expected relationship between the above described factors and individual involvement in entrepreneurial activity. Verheul, Thurik, Hessels and van der Zwan (2010) argue that distinction between opportunity and necessity entrepreneurs is important for several reasons, one of them being the difference between determinants of opportunity and necessity entrepreneurship. In this respect, former empirical research provided some evidence, but it is rather ambiguous. For example, there are no consistent findings on effects of age or educational level (Bergmann \& Sternberg, 2007; Giacomin, Janssen, Guyot \& Lohest, 2011; Verheul et al., 2010; Wagner, 2005). Also, while Giacomin et al. (2011) identified negative effect of having entrepreneurial relatives on necessity entrepreneurship, Verheul et al. (2010) and Wagner (2005) found positive effect of role models on opportunity entrepreneurs, and Morales- 
Gualdrón and Roig (2005) found positive influence of knowing an entrepreneur on both types. Finally, both Wagner (2005) and Morales-Gualdrón and Roig (2005) found fear of failure acting as inhibitor of necessity as well as opportunity entrepreneurial efforts, while Verheul et al. (2010) found no significant effect of this attribute at all.

\section{MATERIAL AND METHODS}

\section{Data and Variables}

The aim of our paper is to analyse the entrepreneurial activity drivers of youth and young adults in V4 countries, considering the opportunity/necessity motivation dichotomy.

Our analysis is based on Global Entrepreneurship Monitor (GEM) data. GEM is the largest academic study dealing with entrepreneurship in the world that annually monitors entrepreneurial attributes and activities (Singer, Amorós \& Arreola, 2015). It uses two main primary data collection instruments - Adult Population Survey (APS) and National Expert Survey (NES). The APS is annually executed in all participating countries and collects individual-level data through a standardized survey instrument administered to representative samples from adult populations (18 to 64 years old). Due to its focus on individuals, representativeness by age and gender on country level, and specific focus on entrepreneurial activity and entrepreneurship-related attributes of individuals, GEM APS data are the most appropriate material to be used in our analysis.

We created a pooled sample using GEM APS individual level data for V4 countries from three consecutive years 2011 to 2013, with age of respondents between 18 to 34 years as the only selection criterion. This resulted to a sample of 9290 young individuals: 2473 (26.6\%) from Czech Republic, 2114 (22.8\%) from Hungary, 2388 (25.7\%) from Slovakia and 2315 (24.9\%) from Poland. This sample contained 313 youth (18 to 24) early-stage entrepreneurs (out of them 231 opportunity-driven and 81 necessity-driven) and 781 young adult early-stage entrepreneurs (out of them 548 running their businesses based on opportunity, and 218 out of necessity). The main sample was further divided into four subsamples - two for analysing the opportunity-driven entrepreneurship (containing non-entrepreneurs and entrepreneurs out of opportunity) among youth and young adults, and other two for the analysis of necessity-driven activity (comprising of non-entrepreneurs and entrepreneurs starting out of necessity) among youth and young adult population.

We employed standard GEM variables in our analysis. The dependent variables indicated involvement of respondents in opportunity- or necessity-driven early-stage entrepreneurial activity. In GEM, total early-stage entrepreneurial activity (TEA) includes individuals actively involved in setting up a business (nascent entrepreneurs) or owningmanaging new firms that are less than 3.5 years old (new entrepreneurs). TEA individuals are further classified according to the reported dominant reason for involvement in business start-up. Those who indicated having no better choices for work are considered as necessity-driven entrepreneurs, while those whose reason was mainly/partially to take advantage of business opportunity, or who were seeking for better opportunities than in their recent jobs, are classified as opportunity-based entrepreneurs.

The explanatory variables employed in our analysis include the following: (1) entrepreneurial self-confidence (belief in having knowledge, skill and experience required to 
start a new business; yes=1, no=0), (2) alertness to opportunities (belief in good opportunities for starting a business in the area where respondent lives in the close future; yes $=1$, no=0), (3) fear of failure (having a fear of failure that would prevent respondent from starting a new business; yes=1, no=0), (4) knowing an entrepreneur (knowing personally someone who started a business in recent two years; yes=1, no=0), (5) perceived status of new entrepreneurs (indicated agreement with statement that in respondent's country, successful new entrepreneurs possess high levels of status and respect; yes=1, no=0), (6) gender (male=1, female=2), (7) education (highest educational attainment), (8) student ("student" indicated as employment status; yes=1, no=0), and (9) household income (total annual household income classified into lowest/middle/upper 33\%-tile for each country). Finally, we also included age and proxies for country and year of survey as control variables.

\section{Hypotheses}

We propose the following hypotheses on entrepreneurial activity drivers among youth and young adults in V4 countries, considering the opportunity/necessity motivation dichotomy:

H1: Entrepreneurial self-confidence is positively related to involvement in both types of entrepreneurship.

H2: Alertness to opportunities is positively related with opportunity entrepreneurship, while it has no significant relation with necessity entrepreneurship.

H3: Fear of failure is negatively related to involvement in both types of entrepreneurship.

H4: Knowing an entrepreneur is positively related to involvement in both types of entrepreneurship.

H5: Perceiving high social status of successful new entrepreneurs is positively related to involvement in both types of entrepreneurship.

Involvement in both opportunity and necessity entrepreneurship is domain of

H6: men, i.e. gender is significantly related to involvement in both types of entrepreneurship.

H7: Educational attainment is positively related to involvement in both types of entrepreneurship.

H8: Student status is negatively related to involvement in both types of entrepreneurship.

Household income is negatively related to involvement in both types of en-

H9: trepreneurship.

\section{Methods}

To identify the drivers of involvement in either opportunity- or necessity-based earlystage entrepreneurial activity among youth and young adults we used a binomial logistic regression modelling. This model estimates the probability of an event happening. In our case this event was owning-managing a business activity based on necessity or opportunity by youth or young adult individuals. Thus, we conducted four regression models 
with two different dependent variables (opportunity-driven and necessity-driven earlystage entrepreneurial activity) for each both age categories. To estimate the parameters of each model we used statistical software R, namely its build-in function for Generalized Linear Models (GLM) which was set on binomial family with logit transformation. The significance of parameters was tested using Wald z-statistics. Maximum likelihood estimations were used to calculate the logit coefficients denoting changes in the log odds of the dependent variable. Correlations between independent variables were tested and proved not to be problematic. The selections of final models were conducted through a stepwise regression function drop1 using Chi-square goodness of fit test, log-likelihood ratio function and Akaike Information Criterion. The selected final models were then compared to the real observation using Hosmer and Lemeshow goodness of fit (GOF) test, which indicated that the models are well fitted.

\section{RESULTS AND DISCUSSION}

\section{Drivers of Opportunity-based Entrepreneurship}

The results of binomial logistic regression conducted to identify the drivers of opportunity-based early-stage entrepreneurial activity among youth and young adult population suggest that nine out of twelve analysed variables are significant (Table 1). Interestingly, except of only two out of the variables that proved significance, all remaining variables were significant in case of both youth as well as young adults.

The estimated coefficients in Table 1 describe the effect of a variable on the odds of engagement in opportunity-driven entrepreneurial activity relative to not being involved in early-stage business at all. If the coefficient value is positive, holding all other variables equal, an increase in a variable raises the likelihood of involvement in business out of opportunity. Therefore, as can be seen from the results, the odds of getting engaged in opportunity-driven early-stage entrepreneurial activity among both youth and young adults are positively related to self-confidence about having entrepreneurial skills (with the highest coefficient value in both models), alertness to good business opportunities, knowing an entrepreneur with recent start-up experience and income level (belonging to middle $33 \%$ tile in case of youth, and to upper 33\% tile in both categories, compared to the lower $33 \%$ tile which was set as a base category). On contrary, in cases of both youth and young adults, having a fear of failure is negatively related to the odds of involvement in opportunity-based business start-up. Moreover, both age categories exhibit significant effect of gender, where being female is negatively related to odds of starting a business based on opportunity. In addition to the common drivers, we have identified also two factors that are specifically significant to individual age categories. In case of youth, student status was found to be significantly reducing the odds of getting engaged in starting an opportunity-based business (with the second strongest influence in the model). In case of young adults, we found significant positive relationship between the odds of starting an opportunity-based early-stage entrepreneurial activity and perception of high societal status of successful new entrepreneurs. As for our control variables, we found positive effect of country affiliation (with Hungary set as a base category) in two cases, with no specific pattern. Age and year of survey were not significant and they were dropped from the final model. 
Table 1. Opportunity-driven entrepreneurial activity drivers (logistic regression results)

\begin{tabular}{|c|c|c|c|c|c|c|c|c|}
\hline \multirow{2}{*}{$\begin{array}{l}\text { Variable / } \\
\text { Measure }\end{array}$} & \multicolumn{4}{|c|}{ Model: Youth } & \multicolumn{4}{|c|}{ Model: Young adults } \\
\hline & Estimate & Std. Error & $Z$ value & $\operatorname{Pr}(>|z|)$ & Estimate & Std. Error & $Z$ value & $\operatorname{Pr}(>|z|)$ \\
\hline (Intercept) & -3.4773 & 0.3417 & -10.1770 & $<2 \mathrm{e}-16$ & -4.3758 & 0.2823 & -15.4990 & $<2 \mathrm{e}-16$ \\
\hline $\begin{array}{l}\text { Self- } \\
\text { confidence }\end{array}$ & 1.6611 & 0.2158 & 7.6960 & $<1 \mathrm{e}-14$ & 1.6673 & 0.1758 & 9.4860 & $<2 \mathrm{e}-16$ \\
\hline $\begin{array}{l}\text { Alertness to } \\
\text { opportunities }\end{array}$ & 0.6155 & 0.1874 & 3.2850 & 0.0010 & 0.4723 & 0.1225 & 3.8540 & 0.0001 \\
\hline Fear of failure & -0.7639 & 0.2019 & -3.7840 & 0.0002 & -0.6342 & 0.1267 & -5.0040 & $<5 e-7$ \\
\hline $\begin{array}{l}\text { Knowing an } \\
\text { entrepreneur }\end{array}$ & 1.1392 & 0.1959 & 5.8160 & $<6 e-9$ & 1.1829 & 0.1336 & 8.8550 & $<2 \mathrm{e}-16$ \\
\hline Gender & -0.7456 & 0.1984 & -3.7580 & 0.0002 & -0.6214 & 0.1290 & -4.8170 & $<1 \mathrm{e}-6$ \\
\hline Student & -1.4296 & 0.3112 & -4.5930 & $<4 \mathrm{e}-6$ & - & - & - & - \\
\hline $\begin{array}{l}\text { Status of } \\
\text { entrepreneur }\end{array}$ & - & - & - & - & 0.2655 & 0.1253 & 2.1190 & 0.0341 \\
\hline $\begin{array}{l}\text { Income: } \\
\text { mid 33\% tile }\end{array}$ & 0.5669 & 0.2687 & 2.1100 & 0.0349 & 0.1935 & 0.1817 & 1.0650 & 0.2869 \\
\hline $\begin{array}{l}\text { Income: } \\
\text { up 33\% tile }\end{array}$ & 0.6838 & 0.2556 & 2.6760 & 0.0075 & 0.4982 & 0.1685 & 2.9560 & 0.0031 \\
\hline Poland & -1.2179 & 0.3024 & -4.0270 & 0.0001 & -0.0002 & 0.2000 & -0.0010 & 0.9994 \\
\hline Czech Rep. & -0.2811 & 0.2675 & -1.0510 & 0.2933 & 0.4628 & 0.1905 & 2.4290 & 0.0152 \\
\hline Slovakia & -0.4801 & 0.2647 & -1.8140 & 0.0697 & 0.1841 & 0.1892 & 0.9730 & 0.3304 \\
\hline Res. dev. & & & & 865.1 & & & & 1932.6 \\
\hline df & & & & 2040 & & & & 3632 \\
\hline Akaike & & & & 889.1 & & & & 1956.6 \\
\hline Log-likelihood & & & & $<1 \mathrm{e}-4$ & & & & 9.7050 \\
\hline p (Chi-sq.) & & & & 0.9992 & & & & 0.0018 \\
\hline HL GOF & & & & 0.9747 & & & & 0.6288 \\
\hline
\end{tabular}

"-“ = variable dropped from the model

Source: own calculations in statistical software R.

\section{Drivers of Necessity-based Entrepreneurship}

As shown in Table 2 below, the results of binomial logistic regression analysis conducted to identify the drivers of youth and young adult involvement in early-stage entrepreneurial activity out of necessity prove significance of seven out of twelve variables. However, the two examined age cohorts have only two common significant drivers, while the remaining variables were found to be significant always for one of the categories only.

As can be seen from the results presented in Table 2, the odds of becoming engaged in necessity-driven entrepreneurial activity in both analysed age categories are positively related to entrepreneurial self-confidence (with strongest effect among all significant variables in both models) and knowing an individual with recent start-up experience. In addition to these two common drivers, we have identified several factors relevant specifically to one of the analysed cohorts. Regarding the youth, we have found that having a fear of failure and being a student significantly inhibit odds of involvement in earlystage business activity out of necessity. Also, we found a significant relationship between income category and odds of starting a business out of necessity (especially for belonging to middle $33 \%$ tile compared to lower $33 \%$ tile which was set as a base category). On contrary, regarding the young adults, we have identified the significant effect of gender, with being female exhibiting negative relationship to the odds of becoming involved in 
necessity-driven entrepreneurial activity. As for the control variables, we have found significant effect of country affiliation (with Hungary set as a base category) in case of young adults, but with no specific pattern. Age and year of survey were found not significant and were dropped from the final model.

Table 2. Necessity-driven entrepreneurial activity drivers (logistic regression results)

\begin{tabular}{|c|c|c|c|c|c|c|c|c|}
\hline \multirow{2}{*}{$\begin{array}{l}\text { Variable / } \\
\text { Measure }\end{array}$} & \multicolumn{4}{|c|}{ Model: Youth } & \multicolumn{4}{|c|}{ Model: Young adults } \\
\hline & Estimate & Std. Error & $Z$ value & $\operatorname{Pr}(>|z|)$ & Estimate & Std. Error & $Z$ value & $\operatorname{Pr}(>|z|)$ \\
\hline (Intercept) & -4.5885 & 0.4224 & -10.8620 & $<2 \mathrm{e}-16$ & -4.6854 & 0.3109 & -15.0690 & $<2 \mathrm{e}-16$ \\
\hline $\begin{array}{l}\text { Self- } \\
\text { confidence }\end{array}$ & 1.7457 & 0.3224 & 5.4140 & 0.0000 & 1.5000 & 0.2359 & 6.3600 & $<2 \mathrm{e}-10$ \\
\hline Fear of failure & -0.7863 & 0.2888 & -2.7230 & 0.0065 & - & - & - & - \\
\hline $\begin{array}{l}\text { Knowing an } \\
\text { entrepreneur }\end{array}$ & 0.6774 & 0.2701 & 2.5080 & 0.0121 & 0.8298 & 0.1845 & 4.4980 & $<6 e-6$ \\
\hline Gender & - & - & - & - & -0.2474 & 0.1770 & -1.3980 & 0.1621 \\
\hline Student & -1.5523 & 0.5254 & -2.9550 & 0.0031 & - & - & - & - \\
\hline $\begin{array}{l}\text { Income: } \\
\text { mid 33\% tile }\end{array}$ & 0.9019 & 0.3608 & 2.4990 & 0.0124 & - & - & - & - \\
\hline $\begin{array}{l}\text { Income: } \\
\text { up 33\% tile }\end{array}$ & 0.0857 & 0.3899 & 0.2200 & 0.8261 & - & - & - & - \\
\hline Poland & - & - & - & - & 0.4215 & 0.2730 & 1.5440 & 0.1226 \\
\hline Czech Rep. & - & - & - & - & -0.2114 & 0.3040 & -0.6960 & 0.4867 \\
\hline Slovakia & - & - & - & - & 0.5431 & 0.2677 & 2.0290 & 0.0425 \\
\hline Res. dev. & & & & 457.2 & & & & 1106.8 \\
\hline $\mathrm{df}$ & & & & 1945 & & & & 3416 \\
\hline Akaike & & & & 489.2 & & & & 1120.8 \\
\hline Log-likelihood & & & & 1.8640 & & & & 2.8200 \\
\hline p (Chi-sq.) & & & & 0.1722 & & & & 0.0931 \\
\hline HL GOF & & & & 0.5407 & & & & 0.9033 \\
\hline
\end{tabular}

"_" = variable dropped from the model

Source: own calculations in statistical software R.

\section{Synthesis, Comparison and Discussion of Findings}

Our findings on significant drivers of opportunity and necessity early-stage entrepreneurship among youth and young adult individuals in V4 countries identify several common drivers together with certain distinctive attributes. Summary of our findings on significance of the hypothesized drivers is provided in Table 3 below. It points out some interesting key findings. First, having the entrepreneurial self-confidence as well as an access to entrepreneurial network (through personally knowing someone who recently started a business) are significantly related to both types of entrepreneurship in both age categories. Moreover, self-confidence exhibits the strongest relation among explanatory variables with similar strength in all four models. On contrary, knowing an entrepreneur was found to have considerably higher strength in case of opportunity-driven entrepreneurial activity. Second, fear of failure significantly inhibits all examined types of entrepreneurship (with very similar strength of the relationship), except of the necessitydriven efforts among young adults. Third, being a female was found to be negatively associated with involvement in opportunity-driven activity in both age cohorts, as well as with involvement in necessity-driven efforts in young adult age category. Fourth, we found that being a student in youth age category significantly inhibits involvement in 
early-stage entrepreneurial activity, irrespective its predominant motivation. Moreover, this factor had the second highest strength in both models. Finally, we found significant positive relationship between income category and all examined alternatives, except of entrepreneurship out of necessity among young adults.

Table 3. Significance of the hypothesized youth entrepreneurship drivers (summary)

\begin{tabular}{|l|c|c|c|c|}
\hline \multirow{2}{*}{\multicolumn{1}{c|}{ Variable }} & \multicolumn{2}{c|}{ Opportunity } & \multicolumn{2}{c|}{ Necessity } \\
\cline { 2 - 5 } & Youth & Young adults & Youth & Young adults \\
\hline Self-confidence & Yes (+) & Yes (+) & Yes (+) & Yes (+) \\
\hline Alertness to opportunities & Yes (+) & Yes (+) & No & No \\
\hline Fear of failure & Yes (-) & Yes (-) & Yes (-) & No \\
\hline Knowing an entrepreneur & Yes (+) & Yes (+) & Yes (+) & Yes (+) \\
\hline Status of entrepreneur & No & Yes (+) & No & No \\
\hline Gender & Yes & Yes & No & Yes \\
\hline Education & No & No & No & No \\
\hline Student & Yes (-) & No & Yes (-) & No \\
\hline Income & Yes (+) & Yes (+) & Yes (+) & No \\
\hline
\end{tabular}

$(+)=$ positive relationship; $(-)=$ negative relationship

Source: own elaboration.

Self-confidence about having skills, knowledge and experience required to start a business was found the most important driver leading both youth and young adults towards engagement in business start-ups, irrespective the motivation in behind. Important role of self-confidence corresponds with the theory establishing it as a component affecting, together with opportunity recognition, the perceived feasibility of entrepreneurial act (Krueger, Reillyb \& Carsrudc, 2000). Also, our findings are in line with empirical research among general entrepreneurial population (Arenius \& Kovalainen, 2006; Koellinger, 2008). Especially related to youth entrepreneurship, our results correspond with findings by Ceptureanu (2015) who identified that almost 8 in 10 young entrepreneurs reported to have strong self-confidence. Moreover, universality of this driver is suggested also by very similar strength of relationship in all our models. Thus, we can conclude that this generally proven driver of entrepreneurial propensity is also valid for young individuals, whether they face opportunity or necessity start-up motivation.

Alertness to good business opportunities was identified as a factor significantly related only with opportunity-driven activity, but both among youth and young adults. In our opinion, this result is rather self-explanatory, since opportunity recognition is an important precondition for involvement in opportunity-based business start-up (e.g. Krueger et al., 2000). Also, previous empirical research has proven the role of opportunity perception as significant business involvement driver (Ramos-Rodríguez, Medina-Garridoa \& Ruiz-Navarrob, 2012; Langowitz \& Minniti, 2007). Regarding young entrepreneurs, study by Ceptureanu (2015) found three quarters of young entrepreneurs positively self-assessing their ability to identify opportunities.

Fear of failure that would prevent one from starting a business was found to be a significant inhibitor of involvement in entrepreneurial activity. The only exception are young adult necessity-driven businesses. To explain this finding, we assume that under the pressure of necessity, young adults (who are usually already economically active and have certain responsibilities to secure income for themselves and their families) are 
more likely to overcome the existent fear of failure and make a step out of their comfort zone towards starting a business activity, than in case they would not be pushed and would consider starting a business based on recognized opportunity, or than their younger counterparts with (generally) no economic responsibilities are. Previous empirical findings related to fear of failure are quite ambiguous, showing significant (RamosRodriguez et al., 2012) as well as no effect (Driga, Lafuente \& Vaillant, 2008), alongside with moderating effect of gender (Koellinger, Minniti \& Schade, 2013; Wagner, 2007). Thus, our results that decompose population of entrepreneurs according to age category and start-up motivation may contribute to explaining the reason for such ambiguity.

Knowing personally an individual with recent start-up experience (our proxy for entrepreneurship-relevant social capital) was found to have significant positive relationship with propensity to both necessity- and opportunity-driven entrepreneurial activity among both youth and young adults, which corresponds with previous empirical findings (Lukes et al., 2013; Ramos-Rodriguez et al., 2012). Interestingly, this relationship is stronger in case of opportunity-driven entrepreneurship. Thus, in our opinion, the nature of this relationship may have different origins in the two types of motives. In case of opportunity, we assume that individuals benefit from their entrepreneurial network mainly in terms of broadening horizons for recognition and creation of business opportunities, and capacity to their exploitation. On contrary, when individuals face the necessity, entrepreneurial network may encourage them to pursue the business start-up path as one of the ways out of necessity, or help them to acquire required resources.

Perceived high societal status of entrepreneurs was found to be significant only in case of opportunity entrepreneurship among young adults, but with rather low strength (as the factor with the lowest strength in the model). Thus, we assume, unlike we hypothesized, that there is no general pattern in relationship between this particular societal attitudes perception, and involvement in business start-up efforts.

Gender was identified as factor significantly influencing the both types of young adults' entrepreneurial activity, as well as the opportunity-based activity of youth. In particular, being a female is negatively related to becoming an early-stage entrepreneur. This is in line with previous findings on uneven representation of women in business activities (Holienka, Jančovičová \& Kovačičová, 2016). However, the exception in case of youth necessity-driven activity suggests that female youth individuals consider entrepreneurship as way out of necessity in similar extent as their male counterparts.

Education was found not to be significantly related to business start-up in none of our models, irrespective the type of motive. Thus, we assume that formal educational attainment is not a relevant human capital component influencing the ability to recognize and exploit business opportunities (therefore fostering opportunity-driven activities), or providing other sufficient occupational options in the necessity situation (thus inhibiting necessity-based business start-ups) among young individuals. Similar findings have been presented by previous empirical studies (Lukeš et al., 2013; Van Der Sluis, Van Praag \& Vijverberg, 2008).

Student status was identified as significant inhibitor of youth involvement in earlystage entrepreneurial activity, irrespective its motivation. In our opinion, this result can be explained by the fact that, generally, youth individuals participating in the educational process do not consider opportunities around them to start a business, nor they are in 
necessity situations, since they do not yet need to be economically active and selfsufficient, and can generally rely on support of their families.

Finally, regarding household income, we found its significant positive relationship to involvement in entrepreneurial activity of young individuals in all cases, except of necessity-driven young adult entrepreneurship. While opportunity-driven entrepreneurship exhibited stronger relationship with the upper income category, it was middle income category in case of necessity-based youth entrepreneurship. Generally, in our opinion, there might be a logical explanation for this situation. We suppose that this relationship does not mean causality from income to entrepreneurial activity, but rather in the opposite direction. In simple words, young individuals probably do not start businesses because of high income of their household, but, vice versa, they rather achieve higher income thanks to being involved in opportunity-based entrepreneurship.

\section{CONCLUSIONS}

Our findings suggest there are several similarities together with certain differences in opportunity- and necessity-driven entrepreneurship drivers among young individuals. According to our results, entrepreneurial self-confidence and access to entrepreneurial network are significantly related to both types of entrepreneurship in both age categories. While fear of failure significantly inhibits all examined types of entrepreneurship except of the necessity-driven efforts among young adults, being a female was found to be negatively associated with involvement in opportunity-driven activity in both age cohorts, as well as with involvement in necessity-driven efforts in young adult age category. Also, being a student was found to be significant inhibitor of enterprising effort of youth irrespective its motivation, and alertness to opportunities was identified as important driver of opportunity-based businesses in both age categories.

Regarding the limitations of our analysis, since all analysed items originate from the same survey, as well as due to the testing method employed, an argument that our findings cannot be unambiguously interpreted as causal relationships could occur (Bosma, 2013). However, the evidence coming from our data is rather strong and based on solid theoretical arguments, so we argue that qualitative nature of our results is correct. Also, due to the nature of our data, we were not able to inquire deeper into the nature of opportunity or necessity, or possibility of their combination. Thus, we recommend these directions to be followed by future entrepreneurship research devoted to the opportunity/necessity perspective. Also, further directions could expand research on youth entrepreneurship from individual to social and institutional levels, using multi-level analytical techniques.

From a policy perspective, our results identify the important factors in relation to support of entrepreneurial activities considering the motivation behind business startup. We show directions for policy makers aiming to foster entrepreneurship within young generation as both a way to exploit available business opportunities, as well as reaction to necessity situations. 


\section{REFERENCES}

Ajzen, I. (1991). The Theory of Planned Behavior. Organizational Behavior and Human Decision Processes, 50(2), 179-211.

Arenius, P., \& Minniti, M. (2005). Perceptual Variables and Nascent Entrepreneurship. Small Business Economics, 24(3), 233-247.

Arenius, P., \& Kovalainen, A. (2006). Similarities and differences across the factors associated with women's self-employment preference in the Nordic countries. International Small Business Journal, 24(1), 31-59.

Bandura, A. (1994). Self-efficacy. In V.S. Ramachaudran (Ed.), Encyclopedia of human behavior (pp. 71-81). Vol. 4. New York: Academic Press.

Bergmann, H., \& Sternberg, R. (2007). The changing face of entrepreneurship in Germany. Small Business Economics, 28(2), 205-221.

Bjerke, B. (2013). About Entrepreneurship. Cheltenham: Edward Elgar.

Bosma, N. (2013). The Global Entrepreneurship Monitor (GEM) and its impact on entrepreneurship research. Foundations and Trends in Entrepreneurship, 9(2), 143-248.

Ceptureanu, S.I. (2015). Romanian Young Entrepreneurs Features: An Empirical Survey. The Annals of the University of Oradea - Economic Sciences, 25(1), 1068-1078.

Davidsson, P., \& Honig, B. (2003). The role of social and human capital among nascent entrepreneurs. Journal of Business Venturing, 18(3), 301-331.

Davis, A.E. (2012). Women's Entrepreneurship. In M.R. Marvel (Ed.), Encyclopedia of New Venture Management (pp. 469-471). Thousand Oaks: Sage Publications.

Driga, O., Lafuente, E., \& Vaillant, Y. (2008). Reasons for the relatively lower entrepreneurial activity levels of rural women in Spain. Sociologia Ruralis, 49(1), 70-96.

European Commission (2009). Youth in Europe. A statistical portrait. 2009 edition. Luxembourg: Publications Office of the EU.

Giacomin, O., Janssen, F., Guyot, J., \& Lohest, O. (2011). Opportunity and/or necessity entrepreneurship? The impact of the socio-economic characteristics of entrepreneurs. MPRA Paper No. 29506. Munich: MPRA.

Holienka, M. (2014). Youth entrepreneurship in Slovakia: a GEM based perspective. Comenius Management Review, 8(2), 41-50.

Holienka, M., Jančovičová, Z., \& Kovačičová, Z. (2016). Drivers of women entrepreneurship in Visegrad countries: GEM evidence. Procedia - Social and Behavioral Sciences, 220, 124-133.

Chigunta, F. (2002). Youth Entrepreneurship: Meeting the Key Policy Challenges. Oxford: Wolfson College, Oxford University.

Integral Assets Consulting (2006). Youth Entrepreneurship. Theory, Practice and Field Development. A Background Paper prepared for the W. K. Kellog Foundation. Retrieved on May 5, 2016 from http://extension.missouri.edu/exceed/documents/YouthEntrepreneurshipKelloggFoundation 2007.pdf

Kew, J., Herrington, M., Litovsky, Y., \& Gale, H. (2013). Generation Entrepreneur? The state of global youth entrepreneurship. London: Youth Business International.

Kim, P.H., Aldrich, H.E., \& Keister, L.A. (2006). Access (Not) Denied: The Impact of Financial, Human, and Cultural Capital on Entrepreneurial Entry in the United States. Small Business Economics, 27(1), 5-22.

Kirzner, I.M. (1979). Perception, opportunity and profit. Chicago: University of Chicago Press. 
Koellinger, P., Minnitic, M., \& Schaded, C. (2007). "I think I can, I think I can": Overconfidence and Entrepreneurial Behavior'. Journal of Economic Psychology, 28(8), 502-527.

Koellinger, P. (2008). Why are some entrepreneurs more innovative than others? Small Business Economics, 31(1), 21-37.

Koellinger, P., Minniti, M., \& Schade, C. (2013). Gender Differences in Entrepreneurial Propensity. Oxford Bulletin of Economics and Statistics, 75(2), 213-234.

Krueger, N.F., Reillyb, M.D., \& Carsrudc, A.L. (2000). Competing models of entrepreneurial intentions. Journal of Business Venturing, 15(5-6), 411-432.

Langowitz, N., \& Minniti, M. (2007). The Entrepreneurial Propensity of Women. Entrepreneurship Theory and Practice, 31(3), 341-364.

Lonsburry, M., \& Glynn, M.A. (2001). Cultural entrepreneurship: stories, legitimacy, and the acquisition of resources. Strategic Management Journal, 22(6-7), 545-564.

Lukeš, M., Zouhar, J., Jakl, M., \& Očko, P. (2013). Faktory ovlivnujici vstup do podnikani: Zacinajici podnikatele v Ceske republice. Politická ekonomie, 61(2), 229-247.

Minola, T., Criaco, G., \& Cassia, L. (2014). Are youth really different? New beliefs for old practices in entrepreneurship. International Journal of Entrepreneurship and Innovation Management, 18(2/3), 233-259.

Morales-Gualdrón, S.T., \& Roig, S. (2005). The new venture decision: an analysis based on the GEM project database. International Entrepreneurship and Management Journal, 1(4), 479-499.

North, D.C. (1990). Institutions, institutional change and economic performance. Cambridge: Cambridge University Press.

Pilková, A., Holienka, M., Kovačicová, Z., \& Rehák, J. (2014). Podnikanie na Slovensku: aktivita, inkluzivita, prostredie. Bratislava: Univerzita Komenskeho v Bratislave, Fakulta managementu.

Portes, A. (1998). Social Capital: Its Origins and Application in Modern Sociology. Annual Review of Sociology, 18, 109-127.

Ramos-Rodríguez, R.A., Medina-Garrido, J.-A., Lorenzo-Gómez, J.-D., \& Ruiz-Navarro, J. (2010). What you know or who you know? The role of intellectual and social capital in opportunity recognition. International Small Business Journal, 28(6), 566-582.

Ramos-Rodríguez, R.A., Medina-Garridoa, J.A., \& Ruiz-Navarrob, J. (2012). Determinants of hotels and restaurants entrepreneurship: A study using GEM data. International Journal of Hospitality Management, 31(2), 579-587.

Reynolds, P.D., Camp, S.M., Bygrave, W.D., Autio, E., \& Hay, M. (2001). Global Entrepreneurship Monitor, 2001 Executive Report. Retrieved on January 10, 2016 from http://unpan1.un.org/intradoc/groups/public/documents/un/unpan002481.pdf

Singer, S., Amorós, J.E., \& Arreola, D.M. (2015). Global Entrepreneurship Monitor 2014 Global Report. London: GERA.

United Nations (2014). Definition of Youth. New York, NY: United Nations Department of Economic and Social Affairs.

Van Der Sluis, J., Van Praag, M., \& Vijverberg, M. (2008). Education and Entrepreneurship Selection and Performance: A Review of the Empirical Literature. Journal of Economic Surveys, 22(5), 795-841.

Verheul, I., Thurik, R., Hessels, J., \& van der Zwan, P. (2010). Factors Influencing the Entrepreneurial Engagement of Opportunity and Necessity Entrepreneurs. EIM Reseacrch Reports No. H201011. Zoetermeer: EIM. 
Wagner, J. (2005). Der Noth gehorchend, nicht dem eignen Trieb - Nascent necessity and opportunity entrepreneurs in Germany: Evidence from the Regional Entrepreneurship Monitor. IZA Discussion Paper No. 1608. Bonn: IZA.

Wagner, J. (2007). What a Difference a $Y$ makes - Female and Male Nascent Entrepreneurs in Germany. Small Business Economics, 28(1), 1-21.

Wong, P.K., \& Lee, L. (2005). Antecedents for entrepreneurial propensity in Singapore. NUS Entrepreneurship Centre working papers No. WP2005-12. Singapore: NUS. 


\section{Authors}

The contribution of co-authors is equal and can be expressed as $34 \%, 33 \%$ and $33 \%$. M. Holienka prepared the results analysis and discussion, A. Pilková prepared the literature review, while Z. Jančovičová prepared the statistical calculations and material and methods.

\section{Marian Holienka}

Post-Doc Assistant Professor and Researcher at Comenius University in Bratislava (Slovakia), Faculty of Management, Department of Strategy and Entrepreneurship. PhD in Business Administration by Comenius University in Bratislava (Slovakia); Degree in Management with major in Strategic Management by Comenius University in Bratislava (Slovakia).

Correspondence to: Mgr. Marian Holienka, PhD; Comenius University in Bratislava; Faculty of Management; Odbojarov 10, 82005 Bratislava, Slovakia; e-mail: marian.holienka@fm.uniba.sk

\section{Anna Pilková}

Associate Professor and Head of Department at Comenius University in Bratislava (Slovakia), Faculty of Management, Department of Strategy and Entrepreneurship. PhD in Economics and Management of Industries - Organization and Management of Industrial Enterprises by University of Economics in Bratislava (Slovakia); MBA by Rochester Institute of Technology (USA); Degree in Economics and Management of Industries by University of Economics in Bratislava (Slovakia).

Correspondence to: Doc. dr. ing. Anna Pilková; Comenius University in Bratislava; Faculty of Management; Odbojarov 10, 82005 Bratislava, Slovakia; e-mail: anna.pilkova@fm.uniba.sk

\section{Zuzana Jančovičová}

Doctoral candidate at Comenius University in Bratislava (Slovakia), Faculty of Management, Department of Economics and Finance. Degree in Managerial Mathematics by Comenius University in Bratislava (Slovakia).

Correspondence to: Ing. Zuzana Jančovičová; Comenius University in Bratislava; Faculty of Management; Odbojarov 10, 82005 Bratislava, Slovakia; e-mail: zuzana.jancovicova@ st.fm.uniba.sk

\section{Acknowledgements and Financial Disclosure}

This work was supported by the Slovak Research and Development Agency under the contract No. APVV-14-0647.

The authors would like to thank the anonymous referees for their useful comments, which allowed to increase the value of this article.

\section{Copyright and License}

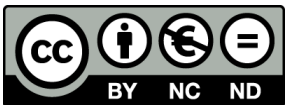

This article is published under the terms of the Creative Commons Attribution - NonCommercial - NoDerivs (CC BY-NC-ND 3.0) License http://creativecommons.org/licenses/by-nc-nd/3.0/ 
